\title{
Commentary
}

\section{ISSUES IN THE PROVISION OF FOOD AID FOLLOWING DISASTERS}

\author{
FRI:DERICK C. C 'UNY \\ INTERTECT, Dallas, Teras
}

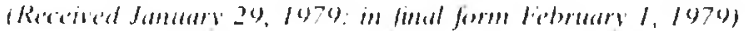

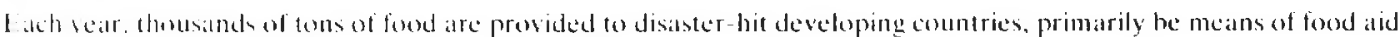

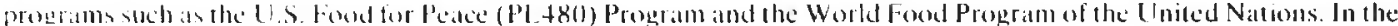
part. in-deptli weds assessment and evaluation studies of the real impact of these programs on the sociedies they are intemded to help hate bech irtudly non-existem. Recent experience and a growing understanding of the problems imsolved in the provision of ford atd indicate that the strategies used and the basic alssumptions under which these

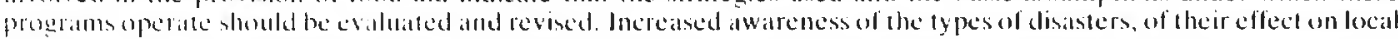

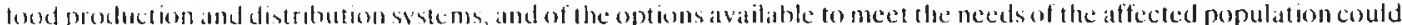

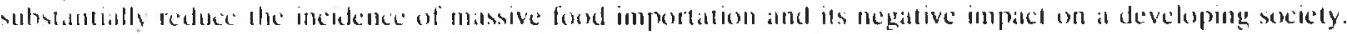

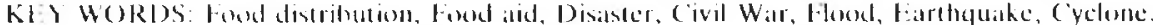

\section{INTRODUCTION}

Eisch year, millioms of tons of food are supplied by food-exporting nations (o) the developing countries. A substantial portion of this food is made avaliable after disasters with the intention of providing emergency and post-disaster supplies to replace food tores lost in the disaster. The United States, Canalla and sustralia are the world's latgest suppliess of emergency food aid. I atst year alome. the United States, through its Pl.480 program (Fond for Peace) supplied 328,000 toms to disatster-bit mationst The (J.S. PI 480 program and the World food Program of the United Nations are the two most important sources of supply. With the growing humbatatrian concern ahout world hunger and the recent awareness of the role that disasters platy in the cycle which retards economic and social development processes a he amount of lond atd which will be available in the future is projected (1) increase.

In recent tean there hats been a trend for postdisaster fond and proghams to continte long past the intial emerency period. Droughts in the Sallel, fatures of the rice crops in Indiat and Banglidesh in paist veats have convinced many program andministraters that al disatster will have a long-term

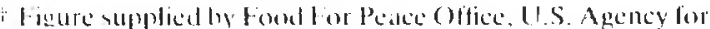

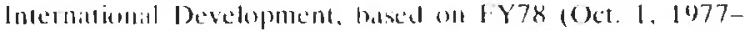
iept $3(1,1978)$. effect on food needs in a region, and that food aid should be continued until such time as food supplies are restored and the markets are fully back in operation.

The mechanisms which exist for supplying emergency food aid following disasters have been set up to meet short-term humanitarian objectives, based upon certain basic assumptions. The first and foremost of these assumptions is that the disaster victim hats lost his supply of food in the disatster. The second is that normal distribution systems are totally disrupled and will be unable to function. The third assumption is that, deve to the disaster, the victims will not have the capital necessatry to lis lood, even if it were available.

Dac to the nature of most emergency and postdisalster programs, few sophisticalted evaluations of the implate of food supplied after a disaster have been conducted, and the above assumptions have gone virtually unchallenged. Only in the last several years has there been a growing concern on the part of administrators that the overall impact of post-disaster food imports maly have far greater negative than positive elfects. From this growing concero, six major yeestions have arisen:

Is food aid necessary?

What is the social and economic impact of large-scale food programs on a country's development?

Is the food provided appropriate? 
If the fond is necessilly. how will it te provided? Daces the provesion of fored aid after al disaster specel of cklat recosers?

Whose needs dese al lond program meet?

\section{DISASIFRS AND FOOOO NEEDS: THE ISSLES}

lo orike to understamel some of the factors att play, it is necessary to examine several different types of disisters. The four disasters that catuse the most

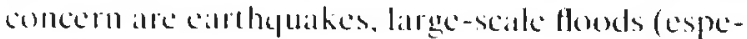
cially those caused by cyclonic storms), prolonged civil distrubances, and dronghts. (AID, 1976)

\section{Case I: Earthquakes}

Earthyuakes are particularly violent disasters and calls affect extremely large regions. In Guatemala in 1976, over one-third of the country's population lived in structures which were damaged or destroyed by the earthquake. Thousinds of people were killed, and transportatoon and communications were distupted throughwat the entire cotuntry. On the surfice, such at disaster would seem to necet the eriteria for massive importation of food: and indeed, a number of agencies immediately began plaming food progrilms. ${ }^{\prime}$

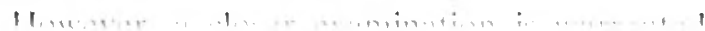

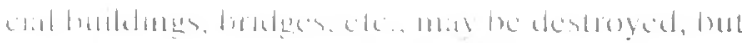
rarely are hod supplies allected. In the calse of Gilatemala, most of the food wits still in the fields. at yet unharvested: thus lood was still availahle. What was needed was a place to store the food, and the rapid restoration of the market network 10 emsure that ford supplies could be distributed. The farvesting and matketing of the foud is the primary economicendeavor of the majority of the people living in the alfected areal. Even affer the disalster, eflurts to hanvest tramsport and market food tosh precedence ower everything except immediatc medical needs. In every focillion. functioning markets were in operanion long lefore massive immounts of food coukd have been distributed by outside domor agencies. Nonetheless, several agencies continued their plans to import food,

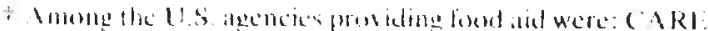

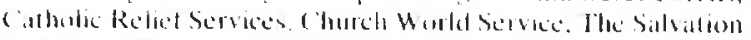
Army and Direct Rolice Foundation. some on the assumption that it was needed, and others in an effort lo improve the nutrition levels of the people throughout the disister-affected region.

Iwo things should be mentioned here. First, the large-scale importation that was planned wats viewed with alarm by the small farmers and the government. They realsoned that large amounts of fond would substantially lower the price the small farmer would receive for the food he had produced. This concern wass so great that several of the relief agencies, affer failing to persuade the others to stop their food programs, attempted to stabilize prices by const ructing large silos and buying foud at the pre-disaster price. Second, those agencies that wanted to improve the nutritional level, using the disaster as a vehicle for initiating change, were working against tremendous odds. Hexperience during the past few years has shown that the primary concern of the disaster victim is to return to normal as quickly as possible, and that change instituted during a disaster rarely takes Jold.\$

\section{Case 11: Civil War}

Food importers argue that such a conflict, especially if it is long-term, distupts transportation and local markets; if the fighting is widespread, it may atow disinpt farming. This rationale was used by ucies for importing massive amounts of wing the civil war in Lebanon in 1976//. In the catse of I.chanon, they also argued that it is a foud-importing nation even during the best of times; therefore, massive emergency supplics would be necessary in the post-conflict period.

However, the Lebanese situation differed from what was immediately evident. First, even during the high points of the fighting, scalscity of food hat never been a problem. Each faction in the civil wat hatd to depend upon the loyalty of mon-combatants within their area of operation and, thus, claborate and rather sophisticated schemes were developed to ensure that food supplies flowed even through the worst of the fighting. Marketing and transpor-

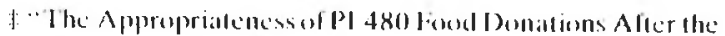
1"76 latlhepuake and in Non-1)isalster l'imes," celited interview with Franciseo Batcihat Pabluand Benilo Sicaljan Sipale, by Rober (iersouly and Tony Jackson, ('himaltenarigo, (iualcemalit, Otober 1977.

\$."Disaster alld (opping Mechanisms in (akchiquel (inalemala: The ( ultural (ontext," Dr. Matgated Kicfler INTERTLC"I, 1977. 
fation of fend from remal areats were inded disrupled: hat in most cates lhe farmers were able to

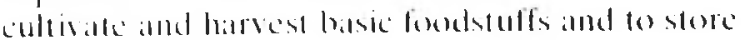
them salels untit he framspertation ststems were restored. fommediate necels alter the lighting ceatsed wete mel be this reserve of food which hecame available when the fighting stopped.

Nevertheless. major relice organizallons immediatels initiated lates-scate importation of ford for the war victims. The food was distributed

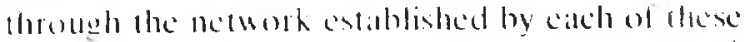
organisaroms and nol through normal marhes.t comcern immediately arose on the part of the farmers about the impact of this food on prices.t They needed wo markel the ir own surplus in order to be able te recoup expenses lost during the periods of fighting. In order lo stabilies prices and phatanted a fat price to the farmers, the govertument initiated a price support program. But what about the fict that Lebanon is normally a food-importing nation? While the cesuntry does import latge amounts of food, it is connected to other countries in the Middle East by an intricate importexport metwork. Post-disaster foud programs operated outside this metwork and, had sufficient quantitics been imported in this manner, it would have had a decidedly negative impict on the recovery of this vital comomic ststem. Had this heen coupled with a widespread lethargic agreutural recovery, the net result could have produced disastrous conseyuences for gears to come.s

\section{C'ase 1ll: Floods}

Fifood situations are often ciled as a justificallwn for post-disister ford programs; a his type of disatsker does destroy food supplies and creates an immediate need for food for the disaster vietims. The primaty yesestion in this calse is not whether the ford is mected. but rather which someces should provide it and through which mechanisms shoubl it he distributed.

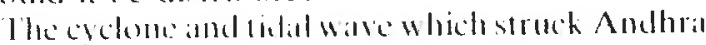
Pratesle. India, in November 1977 pronicles an cocellent recent example. The that wave and high

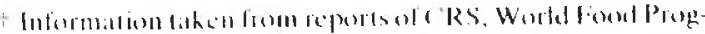

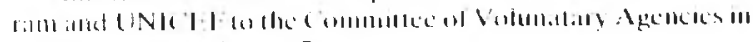

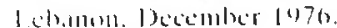

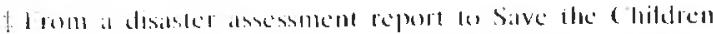

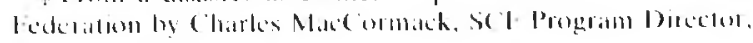
1)ecombil 1970.

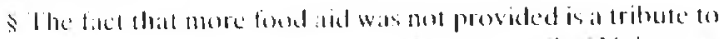

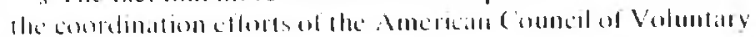
figcolics in New louk winds accompanying the cyclone gencrated floods which destroyed between 70 pereent and 90 percent of fored supplies in the area where the cyclone came ashore. The lidal wave itself struck all area approximallely $30 \mathrm{~km}$. long and $15 \mathrm{~km}$. wide. Foxding in the remainder of the cyclone-affected region dicl exlensive damage in an area of approximatcly 500.000) acres (1171 sepuare miles)-al very substantiall areil. especially when examined oll-site.| To put the damage in perspective, however, the lotal area alfected by the tidal wave represents less than two percent of the total irrigated areal within the two districts where it struck. Wilhin the entire stalle of Andhra Pradesh, the area affected by both wind damage and the tidal wave makes up less than ten percent of the total areat under cultivation. While there was an immediate and pressing need for emergency food supplies in the cyclone-affected region, the surrounding area was largely unaffected.

There was a good crop in 1976 and again in 1977. and surplusses were available. India has at food bank for regional supplies, and the foodstuffs in it were relatively unalfected by the storm. The questions which faced program administrators were: Where should the food be obtatined? How could equal distribution be assured? Should food be imported from outside the country, should it be purchased in surrounding markets, or should it be transferred from the food bank? Or should local markets in the affected areas be stimulated with cash se that normal market activities could take care of the ford deficiency? Those agencies that considered importing food impliced that such programs would be able (u deliver ford faster and more clficiently than would in-country purchase of tood from existing stocks or stimulation of local marhets. (lo this catse, massive importation would mot have been more riple. The mats were quickly resterced: ficw vehickes were destroyed by the cyelonte; and lond begin arriving from surrounding alreats al a very rapid ralle.)

The dearth of available captial for food purchases encouraged several agencies 10 consider food-for-work programs, while oflers argued that this in itself was another incentive for importing food. Agitim, the guestion of what effect foodfor-work or outright gitts of food would have on the local food prodicers and markets was hotly debalted.

He Jaken from datil provided in U.S.A.1.D. Sitrip No. 5.

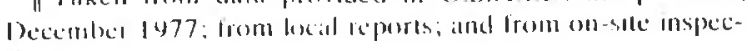
IIIII. 
Severall agencies decided that forol distrihution programs of any type would be it disincentive and aliered instead labor-intensive projects which generatled mach-nesded capital in the area. Their liasoming wats that money injected into the areal would have a far greiater (and decidedly more posiive) impact on recovery than would simple food distribution programs.

\section{Case IV: Droughis}

finally, there is the special calse of drought and massive crop failures. In these cases, are there adequate supplies and marketing mechanisms necessary to meet demands? The long drought in Sithelian Africa satw millions of tons of foodimported over a seven-year period to supply the victims. There is no doubt that thousands of lives were saved due to this effort. But again, haunting luestions remain. Did the imported food have a negative impact on the marketing of food that was av ailable and that was produced in the region? Did the means by which the program was conducted and the way the food was distributed prove to be a disincentive to marginal farmers, adding those people to the ranks of refugees? Was the imported ford similar to that to which the refugees were accustomed? Could food have been purchased in neighboring countries that were not affected by the drought?

There is no doubt that, from the relief agencies' point of view, it was simply casier to purchase food supplies in the exporting countries and ship it in. $f$ lice question remains: does a decision based on cisc of administration serve the neceds of the victim or the donor?

These questions and many others relating to the Silhel will take years to answer. But with the grow: ing sophistication about how food is produced, and the necessity for working through locial systems lateker than outside of them. the resulting perspeclive is likely to be a condemnation of the wholesale importation of ford

\section{GIENERAL, I.ESSONS}

from past experience, then, whalt are the major k'sisens relating to the provision of food following

† for more complete information see: International Disaster Ryense: The Suhelian Experience, Barhara J. Brown, Janet C. lubhall, and E. Thoms Rowe, University of Denver, June 1176 disiasters? For example, what is the effect of a disaster on food needs, and when is the provision of food really necessary?

In order to further understand these issues, it is necessary to divide disasters into two categories: cataclysmic disasters, and long-term continuing Jisasters. In the cattaclysmic disaster, there is usually one large-scalle event which occurs, doing most of the damage and destruction. Following this single event, there may be a tremendous amount of suffering and chaos, hut generally things begin to get better as time passes. In a continuing disaster, the situation remains constant or may even deteriorate as time passes. Cataclysmic disasters include earthquakes, volcanic eruptions, cyclonic storms and floods. Continuing disasters include prolonged civil strife, crop failures and droughts.

The damaged area in a cataclysmic disaster is usually relatively small, while the area affected in a continuing disuster can be extremely large. In terms of food and food distribution, cataclysmic disasters are normally more disruptivethandestructive. For example, they may disrupt the transport of goods and the marketing system. They can disrupt or damage irrigution systems. To a limited extent, they do destroy food supplies, but the amount of destruction de pends on the season, the location of the disaster, and the total area affected. On the other hand, continuing disasters not only disrupt transportation and distribution networks, but can often bring them to a long halt and ultimately destroy the system itself. (An excellent example is the effect of the drought on the traditional barter/exchange system of the Taureg nomades in Niger. Due to the extended drought, many Tauregs were forced to become sedentary and to enter the money economy.)

When, then, is food necessary? Food must be provided whenever victims are denied long-term access to normal markets, or when the local market system is not capable of meeting the demand for forod. In the vast majority of cases, these conditions exist only in the continuing disaster.

The next question for an administrator is: What is the hest form of food assistance? There are no simple answers to this, and the easy access of many privale voluntary agencies to PL480 and World Food Program stucks has obscured the realization that simple food distribution programs may not be the best answer and that other options exist. In most disasters, agencies find themselves responding to a problem by addressing the products of that problem rather than its cuuses. Most agencies ure 
soblinded by the short-term immediate needs that they fail to cxamine closely the mpact of the program they develop to alleviate shut-term neods, and they lail to examine the long-term impact of the program on the affected society.

If the find programs develuped alter disasters have had sueh a negative impalet on the socieries they were intended to help, why are they contimued? First of all, the sophistication required in assessing the impact of these programs has only recently been developed. In the past, the causeand-effect relationships at play (and especially the long-term impact of these programs on a society, both socially and economically), have not been well understood. nor have ihey been clusely axtmimed. Interest in this fiets hats only recently hecome more widespread and as yet, few of the agencies involved in food distribution programs have acquired the capabilities to conduct such assessments.

Secondly. atgencies are often atught in the "speed" symarome. A disister crealles tremendous pressures within an organization to respond quickly, to make its choices ahout program options rapilly, and gencrally to get things moving as quakly as possible. Pressures are exerted by the disaster victims themselves, the local government, the press and, most importitntly from the agencies' point of view, hy the agencies' donors. Agencies fear that, if they do not take immediate action, both the opportunity and the funds will not be avalibble at a later date. In this rush to action, neceds assessment and sophisticated analysis of existing supplies, matheting systems, elc, go by the wayside.t

Puhlic pressure exerted on an ageney to import ford alter a disaster is based on a misunderstanding of both actual needs and of the problems movolved in this type of progrim. The general public labors under' a very unsophisticated set of assumptions ahout developing countries, and surplusises from the industrialized countries alse often seerl as a simple expedient for solving Third World problems. All the major relicf and development organizations must be called to talsk for the ir failure to communicate the realites to the ir donors arrd to the public at large.

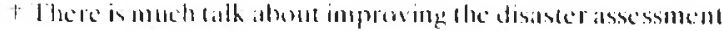

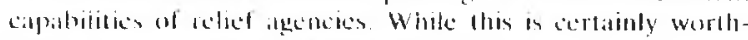

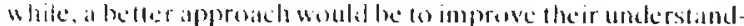
ing of an area hing belone a disater slrokes. In short, if an agency has not been involved in an areat before a disaster

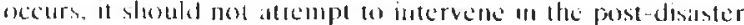
perioul.
There is a final factor which serves to perpetuate food aid programs, and it is this factor which has drath most of the recent criticism. The food aid system has built-in incentives that reward massive distribution of stuplus food. In the U.S. PL480 program, for installec, an agency that distributes PL 480 food receives not only the food for distribution but also moncy lor support of the staff involved in the distribution and a grant proportional to the tonnage delivered to defray overhead expenses. For some non-profit orgnaizations, this arrangement can be a godsend; and a number of agencies receive a substantial portion of their operating funds for simply administering the various PL480 programs. There is nothing, of course, which would prevent an agency from purchasing post-disister food supplies locally or from the surrounding area. But when presented with a choice of expending funds to do so with no cash return, or utilizing PL480 foodstuffs and receiving, in effect, a bonus for doing so, it can be seen that the PL480 program is a disincentive to agencies which would otherwise use their resources to stimulate recovery of local lood distribution systems.

\section{FUTURE DIREC'TIONS}

What then is the future of food aid programs following disasters? Most assuredly, criticism will continue to mount not only concerning the way food programs are administered, but also concerning the impact they have on the societies they are intended to help. 'The essential question will be raised time and agatin: Whose needs does the program meet - those of the disaster victims, the donor agencies, or the food producers of the industrialized nations?

Many disaster experts predict at trend awaly from the provision of post-disaster food assistance, loward the provision of capital-intensive projects after a disister that will help re-start the normal food distribution processes. Other disaster specialists are calling for increased atwareness of the opportunities avalable in adequate pre-disaster plannimg/mitigation measures to prevent largescale food shortages following a disaster. For example, they point out that those areas that are subject to drought and or crop failures are, even in the best of times, marginal areas; these areas can be identified long before a disatser strikes and agencies can work to improve the agriculture in 
the se regions so that the eftects of a disaster cath the reduced. if not eliminated.

There ale no simple ansuces to the isstles ratised in the prosisionol ferod aid. But it is vital that these issles be sontronted and examined. Our tunderstamding of hosh disasters and the impated of disatster assistance programs must continue to increase if meaningful changes are to be made in the intermational relicf system.

\section{RIFIRLNCI}

All) (1976) Internatimal Disaster Preparedness Seminar Workbork. (I.S. Apency for Intermational Development, Wishington, D.C. 